\title{
Conjunctive use of rainfall and irrigation for wheat crop in North Nile Delta
}

\author{
Ibrahim M. Abdel-Fattah ${ }^{(1)}$ and Dalia A. Elhag (2) \\ 1- Soils, Water and Environment Research Institute, Agricultural Research Center (ARC). \\ 2- Agronomy Dept., Fac. of Agriculture, Kafr El- Sheikh University
}

\begin{abstract}
To find out the impact of rainfall and irrigation on wheat crop and its water functions, a field trial was carried out at Sakha Agricultural Research Station, North Nile Delta during the two seasons 2015/16 and 2016/17. Treatment Awhichconsists of rainfall only has the lowest applied water (Wa), consumption use (CU) and crop yield, The traditional irrigationtreatment $\mathrm{E}$ consists of no missing irrigation at any growth stage.Average contributionof rainfall in water applied was52.5, 32.4, 32.8, 32.3 and $27.1 \%$ for treatments A, B ( skipping irrigationduring vegetation), $\mathrm{C}$ (skipping irrigation during flowering stage), D (missing irrigation during milking stage) and E (no skipping irrigation), respectively. Skipping irrigation during vegetation stage caused a slightdecrease in wheat yield. In comparison with thetraditional treatment, mean water savings were $48.5,16.5,17.4$ and $16.3 \%$, while the decrease in crop yield was 43.4, 21.2, 11.2 and $5.9 \%$ for treatments A, B, $\mathrm{C}$ and D, respectively. Most of yield components showed similar trends with those of applied water.

Rainfall in the area could partially offset the water needs of wheat crop decreasing the amount of applied irrigation water and ultimately increasing the lifetime of irrigation network infrastructures.
\end{abstract}

Keywords: conjunction use of rainfall and irrigation, water productivity, productivity of applied water and water saving.

\section{Introduction}

Egypt is facing a serious water shortage which is expected to increase in the future. The negative effect of water deficit is pronounced in the per capita share ofwater whichis less than the water poverty edge of $1000 \mathrm{~m}^{3}$. Water shortage is increasing rapidly to reach the water scarcity level of lessthan $500 \mathrm{~m}^{3}$ per annum per individual inhabitant. At this water situation, it is difficult to make any progress in any national economic sector of development.

Irrigated agriculture is very important in meeting food and fiber needs of the increasing global population. Growing demands for water increase the need for irrigated agriculture to become more efficient. Future irrigation management systems will have to utilize water and energy resources more efficiently. One way to increase efficiency is to improve the conjunctive use of rainfall and irrigation water.

The conjunctive use of rainfall and irrigation offers considerable potentials for increasing wateruse efficiency or so-called crop water productivity. The traditional method of irrigation in arid regions is to apply fixed amounts of irrigation water at fixed time intervals. In essence, this method tends to ignore precipitation.

The most common irrigation management objective is to eliminate water as the productionlimiting variable while minimizing excessive application. In most arid regions where irrigation is practiced, sufficient water is made available for theland area irrigated. Therefore rainfall during the irrigation season is generally not considered an essential part of the water requirements. Only when significant amounts of precipitation occur, irrigation events could be delayed. This will conserve water and energy, but it usually has no major effect on yield or on the amount of land irrigated.

Rainfall in semiarid regions is sufficient to allow some crop production without irrigation, but yields are normally low, and crop failure often occurs when less than average precipitation occurs.

There are some measures whichshould be taken regarding maximizing the benefits of conjunction use of rainfall and irrigation. Theycould be summarizedin the following points:

i-Rainfall distribution.

ii- Limited irrigation.

iii- Yield, evapotranspiration and seasonal water application.

iv- Increased efficiency of soil water storage.

v- Conservation tillage.

In general, the conjunctive use of rainfall and irrigation isa tool in water saving by decreasing the amount of irrigation water applied, depending upon the compensation portion of rainfall. Therefore, the amount of irrigation water stored in the water network controlled by Ministry of Water Resources and Irrigation (MWRI) would also decrease which would in return enlarge the life time of the storage capacity of such infrastructures.

Staricka et al (2016) reported that improving irrigation management is critical. If irrigation amounts could be reduced without adversely affecting crop yield and quality, these challenges will be lessened. Water saved from reducing irrigation on land already being irrigated will allow additional land to be irrigated. 
Kharrou et al (2011) demonstrated that drip irrigation applied to wheat was more efficient with $20 \%$ of water saving, $28 \%$ higher yield and $24 \%$ higher water use efficiency in comparison with surface irrigation (full irrigation).

As recommended by AGRI-FACTS (2011), applying irrigation just before the available soil water is depleted to $50 \%$ during wheat pre-flowering growth stage and $60 \%$ between early heading and physiologic maturity as well as replenishing available soil water near field capacity in the appropriate root zones assists in producing a high quality and high-yielding winter wheat crop. Kirkpatrick et al (2006) summarized the irrigation principles of spring grain wheat as follows: (1) avoiding irrigation during early vegetative stages, unless signs of stress appear, (2) monitoring soil moisture, and applying water to promote deep, extensive rooting, (3) ensuring adequate moisture during critical growth stages, and (4) scheduling the final irrigation to carry the crop through harvest..
Panda et al (2003) stated that under water scarcity condition, when soil water stress is imposed during non-critical stages of growth, irrigation must be scheduled at $45 \%$ maximum allowable depletion of available soil water.

The main objective ofthe current study was to assess the implicationsof theconjunctive use of rainfall and irrigation on wheat productivity.

\section{Materials and Methods}

A field experiment was carried out during the two successive wheat-growing seasons 2015/16 and 2016/17 at the research farm of Sakha Agricultural Research Station. The site is located in middle North of Nile Deltaarea with $30^{\circ}-57^{\prime} \mathrm{N}$ latitude, $31^{\circ}-07^{\prime} \mathrm{E}$ longitude with anelevation of about 6 metres above mean sea level. Table 1 represents the climatic elements of the area during the two field trial seasons. The soil of the site is clayey in texture as shown in Table 2.

Table 1. Climaticdata; air temperature $\left(\mathrm{T}, \mathrm{C}^{\circ}\right)$, mean relative humidity $(\mathrm{RH}, \%)$, wind speed $\left(\mathrm{U}_{2}, \mathrm{msec}^{-1}\right)$, evaporation pan $\left(\mathrm{Ep}, \mathrm{mmd}^{-1}\right)$ and rainfall $(\mathrm{Rf}, \mathrm{mm})$.

\begin{tabular}{|c|c|c|c|c|c|c|c|}
\hline \multirow[t]{2}{*}{ Month } & \multicolumn{3}{|c|}{$\mathbf{T},\left({ }^{\circ} \mathbf{C}\right)$} & \multirow{2}{*}{$\begin{array}{l}\mathbf{R H}, \\
\%\end{array}$} & \multirow{2}{*}{$\begin{array}{l}\mathrm{U}_{2}, \\
\text { msec }^{-1}\end{array}$} & \multirow{2}{*}{$\begin{array}{l}\text { Ep, } \\
\text { mmd }^{-1}\end{array}$} & \multirow{2}{*}{$\begin{array}{l}\text { Rf, } \\
\text { mm }\end{array}$} \\
\hline & $\max$ & $\min$ & mean & & & & \\
\hline Nov.2015 & 24.8 & 14.4 & 19.6 & 75.6 & 0.85 & 2.4 & 52.4 \\
\hline Dec." & 20.4 & 8.3 & 14.3 & 78.3 & 0.67 & 2.2 & 25.0 \\
\hline Jan.2016 & 18.4 & 6.3 & 12.3 & 74.1 & 0.80 & 2.4 & 42.7 \\
\hline Feb." & 22.5 & 6.7 & 14.6 & 70.0 & 0.67 & 2.5 & - \\
\hline Mar." & 23.7 & 11.6 & 17.6 & 69.8 & 0.74 & 3.6 & 13.2 \\
\hline Apr." & 30.0 & 19.2 & 24.6 & 61.7 & 1.01 & 6.0 & - \\
\hline May" & 23.3 & 18.8 & 24.5 & 61.7 & 1.3 & 7.2 & 0.0 \\
\hline Seasonal & 23.3 & 11.7 & 17.2 & 70.2 & 0.86 & 3.8 & 133.3 \\
\hline \multicolumn{8}{|c|}{ b-2 ${ }^{\text {nd }}$ season, $2016 / 2017$} \\
\hline \multirow[t]{2}{*}{ Month } & \multicolumn{3}{|c|}{$\mathbf{T},\left({ }^{\circ} \mathbf{C}\right)$} & \multirow{2}{*}{$\begin{array}{l}\mathbf{R H}, \\
\%\end{array}$} & \multirow{2}{*}{$\begin{array}{l}\mathrm{U}_{2} \\
\text { msec }^{-1}\end{array}$} & \multirow{2}{*}{$\begin{array}{l}\text { Ep, } \\
\text { mmd }^{-1}\end{array}$} & \multirow{2}{*}{$\begin{array}{l}\text { Rf, } \\
\text { mm }\end{array}$} \\
\hline & $\max$ & $\min$ & mean & & & & \\
\hline Nov.2016 & 24.9 & 17.9 & 21.4 & 67.4 & 0.88 & 2.0 & 22.0 \\
\hline Dec." & 19.7 & 10.7 & 15.2 & 75.4 & 0.72 & 1.5 & 25.8 \\
\hline Jan.2017 & 18.2 & 5.7 & 11.9 & 75.1 & 0.60 & 1.4 & 19.6 \\
\hline Feb." & 19.6 & 9.8 & 14.7 & 73.0 & 0.73 & 2.0 & 25.2 \\
\hline Mar." & 22.5 & 18.0 & 20.2 & 72.6 & 0.97 & 3.0 & - \\
\hline Apr." & 26.5 & 21.6 & 24.1 & 65.1 & 1.0 & 4.5 & 10.6 \\
\hline May" & 30.6 & 25.8 & 28.2 & 61.6 & 1.23 & 7.3 & - \\
\hline Seasonal & 23.1 & 15.6 & 19.4 & 70.0 & 0.88 & 3.1 & 103.2 \\
\hline
\end{tabular}

\section{Soil analysis.}

Soil samples fromdepths: 0-15, 15-30, 30-45 and $45-60 \mathrm{~cm}$ were collected to determine properties of the soil including field capacity (FC) and permanent wilting point (WP) according to James (1988), bulk density ( $\mathrm{Db}$ ) andparticle size distribution according toKlute(1986). The soil texture is clay as shown in Table 2. Chemical properties of total soluble salts, $\mathrm{pH}$ were determined according To Jackson (1973). Table 2 shows results of soil analysis.

\section{Agronomic practices:}

All agricultural practiceswere executed asthe local farmersdone in the area based on the recommendations of Agricultural Research Center (ARC) except irrigation. The wheat cultivarwas Misr2. Sowing date $(\mathrm{S})$ and harvesting date $(\mathrm{H})$ in the two growing seasons were:

First season: (S) 20/11/2015 and(H) 21/5/2016

Second season: (S)22/11/2016and (H) 22/5/2017

\section{Irrigation treatments:}

Irrigation treatments were done based on rainfall and physiological growth stages of wheat as follows: 
Treatment A: rainfall treatment i.e. given only the planting irrigation.

Treatment B: skipping irrigation during vegetative growth stage.

Treatment C: skippingirrigationduring flowering stage.
Treatment D: skipping irrigation during milking stage.

Treatment E: irrigation during all growth stages (reference treatment).

Table 2. Particle Size distribution and soil water constants of the studied experimental site.

\begin{tabular}{lllllllll}
\hline $\begin{array}{l}\text { Soil } \\
\begin{array}{l}\text { Depth, } \\
\text { cm. }\end{array}\end{array}$ & $\begin{array}{l}\text { Particle Size Distribution } \\
\text { Sand, } \%\end{array}$ & Silt, $\%$ & Clay, $\%$ & $\begin{array}{l}\text { Texture } \\
\text { Class }\end{array}$ & $\begin{array}{l}\text { F.C, } \\
\%\end{array}$ & $\begin{array}{l}\text { W.P, } \\
\%\end{array}$ & $\begin{array}{l}\text { AW, } \\
\%\end{array}$ & $\begin{array}{l}\text { Db, } \\
\text { Mgm }^{-3}\end{array}$ \\
\hline $0-15$ & 18.7 & 29.7 & 51.6 & Clay & 44.61 & 24.24 & 20.37 & 1.05 \\
$15-30$ & 20.5 & 29.5 & 50.0 & & Clay 40.20 & 21.85 & 18.35 & 1.11 \\
$30-45$ & 28.2 & 21.5 & 50.3 & & Clay 38.70 & 21.03 & 17.67 & 1.16 \\
$45-60$ & 25.7 & 26.0 & 48.3 & Clay & 36.30 & 19.73 & 16.57 & 1.20 \\
Mean & 23.2 & 26.7 & 50.1 & Clay & 39.95 & 21.71 & 18.24 & 1.13 \\
\hline
\end{tabular}

Where: $\mathrm{FC}, \%=$ soil field capacity, WP, $\%$ = wilting point, $\mathrm{AW}, \%=$ available soil water, and $\mathrm{Db}, \mathrm{Mgm}^{-3}=$ soil bulk density.

Table 3. Chemical properties of the experimental site:

\begin{tabular}{|c|c|c|c|c|c|c|c|c|c|c|}
\hline \multirow{2}{*}{$\begin{array}{l}\text { Soil } \\
\text { depth, } \\
\mathrm{cm}\end{array}$} & \multirow{2}{*}{$\begin{array}{l}\text { EC*, } \\
\text { dSm }{ }^{-1} \\
\text { paste } \\
\text { extract }\end{array}$} & \multirow{2}{*}{$\begin{array}{l}\mathrm{PH} \\
(1: 2.5) \\
\text { soil water } \\
\text { suspension }\end{array}$} & \multicolumn{8}{|c|}{ Soluble ions, mmole $\mathrm{kg}^{-1}$} \\
\hline & & & $\mathrm{Ca}^{++}$ & $\mathrm{Mg}^{++}$ & $\mathrm{Na}^{+}$ & $\mathrm{K}^{+}$ & $\mathrm{CO}_{3}^{--}$ & $\mathrm{HCO}_{3}^{-}$ & $\mathrm{Cl}^{-}$ & $\mathrm{SO}_{4}^{--}$ \\
\hline $0-15$ & 1.83 & 8.11 & 7.31 & 2.18 & 8.70 & 0.22 & 0.00 & 4.3 & 9.0 & 5.11 \\
\hline $15-30$ & 2.45 & 8.19 & 9.54 & 5.10 & 9.60 & 0.19 & 0.00 & 3.9 & 8.9 & 11.63 \\
\hline $30-45$ & 2.56 & 8.15 & 9.67 & 5.47 & 10.02 & 0.18 & 0.00 & 3.7 & 7.8 & 13.84 \\
\hline $45-60$ & 3.01 & 7.92 & 11.50 & 6.28 & 12.00 & 0.17 & 0.00 & 3.6 & 7.0 & 19.35 \\
\hline Mean & 2.46 & & 9.51 & 4.76 & 10.08 & 0.19 & 0.00 & 3.88 & 8.18 & 12.48 \\
\hline
\end{tabular}

* EC of saturation extract

\section{Data collection:}

a. Water parameters:

\section{- Irrigation water (IW)}

Irrigation water was controlled and measured by contracted rectangular weir,water discharge was calculated asfollows (Michael, 1978):

$\mathrm{Q}=0.0184(\mathrm{~L}-0.2 \mathrm{H}) \mathrm{H}^{1.5}$

In which:

$\mathrm{Q}=$ discharge of the weir, liter/second

$\mathrm{L}=$ width of crest, $\mathrm{cm}$

$\mathrm{H}=$ head over the crest, $\mathrm{cm}$.

\section{- $\quad$ Effective rainfall $\left(\mathbf{R f}_{\mathrm{e}}\right)$}

Effective rainfall $\left(\mathrm{Rf}_{\mathrm{e}}\right)$ is considered as the useful portion of rainfall used in crop water consumption which equaled rainfall multiplied by 0.7 (Novica,1979).Therefore, the values of $\mathrm{Rf}_{\mathrm{e}}$ took the same trend of total rainfall.

Effective rainfall is explained by Allen (1991) who pointed out that not all rainfall is effective in fulfilling irrigation water requirements. Reasons include:

1. Surface runoff due to high rainfall intensity. 2. Deep percolation from heavy rainfall occurring immediately following an irrigation or previous rainfall event.

3.Evaporation of intercepted rain on plant leaves

\section{- Applied water (Wa)}

Applied waterequaled irrigation water (IW) plus rainfall (Rf).

- Consumptive use (CU)

Actual consumptive use (CU) or so-called crop evapotranspiration $\left(\mathrm{ET}_{\mathrm{c}}\right)$ was determined based on soil moisture depletion in the effective root zone of $60 \mathrm{~cm}$ as follows(Hansen et al,1979):

Where: $\quad \mathrm{Cu}=\frac{F C-\theta}{100} * \frac{D b}{D w} * d$

$\mathrm{CU}=$ consumptive use or actual crop water consumed, $\mathrm{cm}$.

$\mathrm{FC}=$ percent ofsoil moisture content on weight basis at field capacity

$\Theta=$ percent soil moisture content on weight basis before each irrigation as well as at harvesting.

$\mathrm{Db}=$ bulk density $\left(\mathrm{Mgm}^{-3}\right)$

Dw $=$ density of water $\left(\mathrm{Mgm}^{-3}\right)$

$\mathrm{d}=$ effective root zone of $60 \mathrm{~cm}$.

It should be noted that soil moisture depletion includes the effective rainfall $\left(\mathrm{Rf}_{\mathrm{e}}\right)$ as described.

\section{- Crop-water functions}

1. Water productivity (WP):

Water productivity as defined by Bos (1980)is the capability of crop water consumed in producing the economic yield as follows (expressed as kg per cubic meter of water).

$\mathrm{WP}=\mathrm{Y} / \mathrm{CU}$ 
Where:

$\mathrm{WP}=$ water productivity $\left(\mathrm{kg} \mathrm{m}^{-3}\right.$ water consumed $)$

$\mathrm{Y}=$ economic yield $(\mathrm{kg})$

$\mathrm{CU}=$ crop-water consumption $\left(\mathrm{m}^{3}\right)$.

\section{Productivity of water applied (PWa):}

This parameter ofPWais the capability of water applied in producing marketable yield according to Bos (1980).

$\mathbf{P W a}=\mathrm{Y} / \mathrm{Wa}$

Where:

PWa = productivity of water applied $\left(\mathrm{kg} \mathrm{m}^{-3}\right)$,

$\mathbf{Y}=$ economicyield $(\mathrm{kg})$

$\mathbf{W a}=$ water applied $\left(\mathrm{m}^{3}\right)$.

B. Vegetative plant traits, yield and yield components:

1- plant height at harvest. 2-1000-grain weight.

3- (grains+straw) yield. 4- grain yield.

5- straw yield. 6- harvest index.

Harvest index $=($ Grain yield $/$ Biological yield $)$

\section{Results and discussions:}

\section{Effective rainfall $\left(\mathbf{R f}_{\mathrm{e}}\right)$}

Values of seasonal rainfall for the two experimental seasons are tabulated in Table 1.Rainfall distribution was from November through April. Thus rainfall is distributed during the wheat growing season, andcould be considered as a portion of applied water to the crop. Mean monthlyrainfallcan be arranged in descending order as follows: 37.20>31.25>25.42>12.60>6.60>5.30 $\mathrm{mm}$ for November, January, December, February, March and April, respectively. Average seasonal rainfall was $118.3 \mathrm{~mm}$ i.e. $1183 \mathrm{~m}^{3} \mathrm{ha}^{-1}(1 \mathrm{fed}=0.42 \mathrm{ha})$ which partially compensates water needs of some winter crops such as wheat.Effective rainfall ( $\mathrm{Rfe}$ ) is rainfall multiplied by 0.7 .

\section{Applied water (Wa)}

Values of seasonal applied water (Wa) which consists of irrigation water (IW) and rainfall (Rf) presented in Table 4 and illustrated in Fig 1 revealthat the highest $\mathrm{Wa}$ was assigned with the full irrigation treatment $\mathrm{E}$ with 4 irrigations including the sowing watering. With no skipping of irrigation, the amount of water was highest in comparison with rainfall treatment $\mathrm{A}$ and/or skipping irrigation treatments of $\mathrm{B}, \mathrm{C}$ and $\mathrm{D}$. The lowest value of $\mathrm{Wa}$ was recorded with the rainfall treatment $\mathrm{A}$ which occurred only at sowing and then left to rainfall during the whole growing season. Therefore, averages of Wafor the two seasons can be arranged in a descending order as;437.3>365.9>365.1>361.1> $225.4 \mathrm{~mm}$ for treatments $\mathrm{E}, \mathrm{D}, \mathrm{B}, \mathrm{C}$ and $\mathrm{A}$, respectively. The mean contribution percentages of rainfall (Rf) in applied water (Wa) were 52.5, 32.4, $32.8,32.3$ and $27.1 \%$ for treatments A, B, C, D and $\mathrm{E}$, respectively. This has twoadvantages of (a) rainfall partially fulfilling crop water needs and (b) consequently decreasing the amount of irrigation water needed for the crop, particularly under the status of water shortage.

The obtained resultsare in harmony with that obtained byCarter and Stoker (1985)concluded similarfindings.Harris et al.(2012) stated that seasonal water requirement for wheat varies from 360 to $550 \mathrm{~mm}$. A full as well as limited irrigation strategies can be used. The period leading up to and including flowering is the most sensitive to water stress., Neibling et al. (2017) reported that field experience of long-time studies indicated that when the final irrigation is applied to refill the profile of sandy-loam or silt-loam soils to field capacity at the soft dough stage, sufficient water can be stored in the soil to meet the crop water requirement until harvest.

Table 4. Seasonalapplied water (Wa); irrigation water (IW) and total rainfall (RF) for wheat crop as affected by irrigation treatments.

a- $1^{\text {st }}$ season, 2015/2016

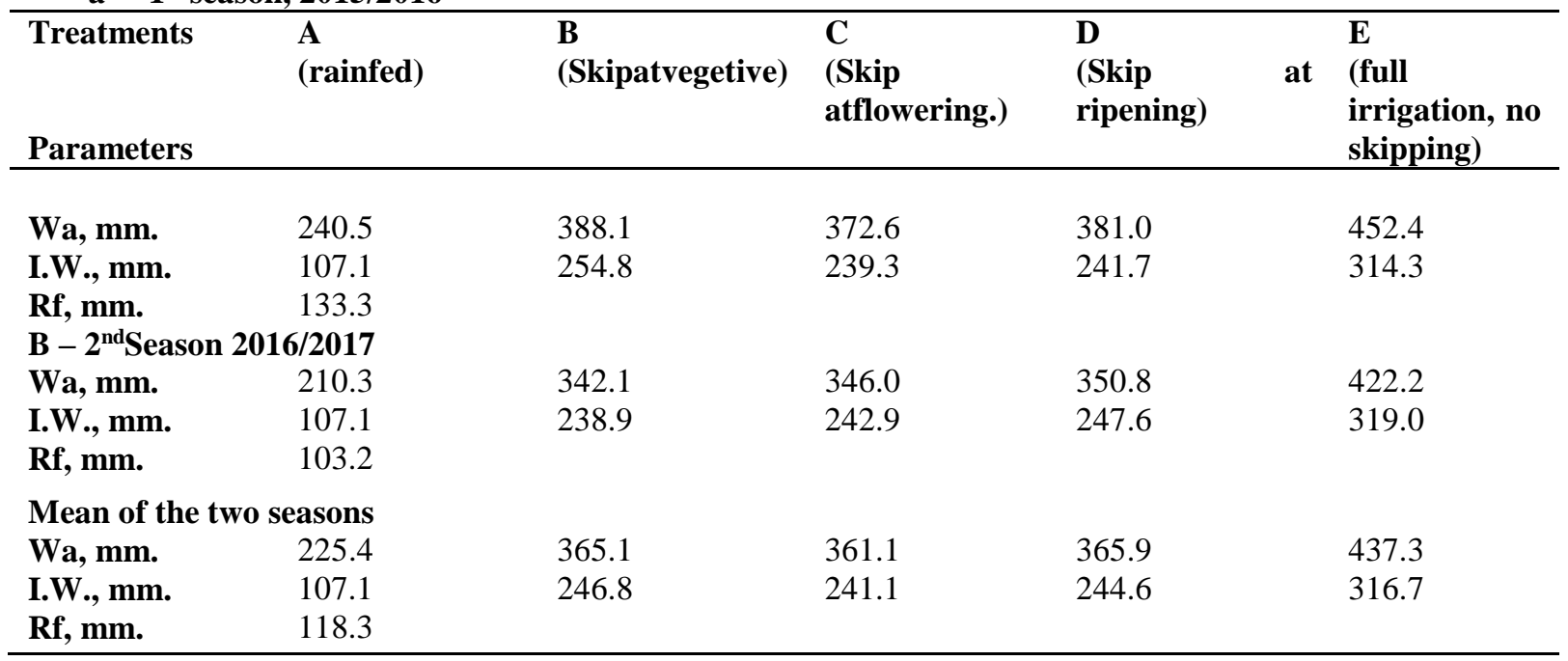




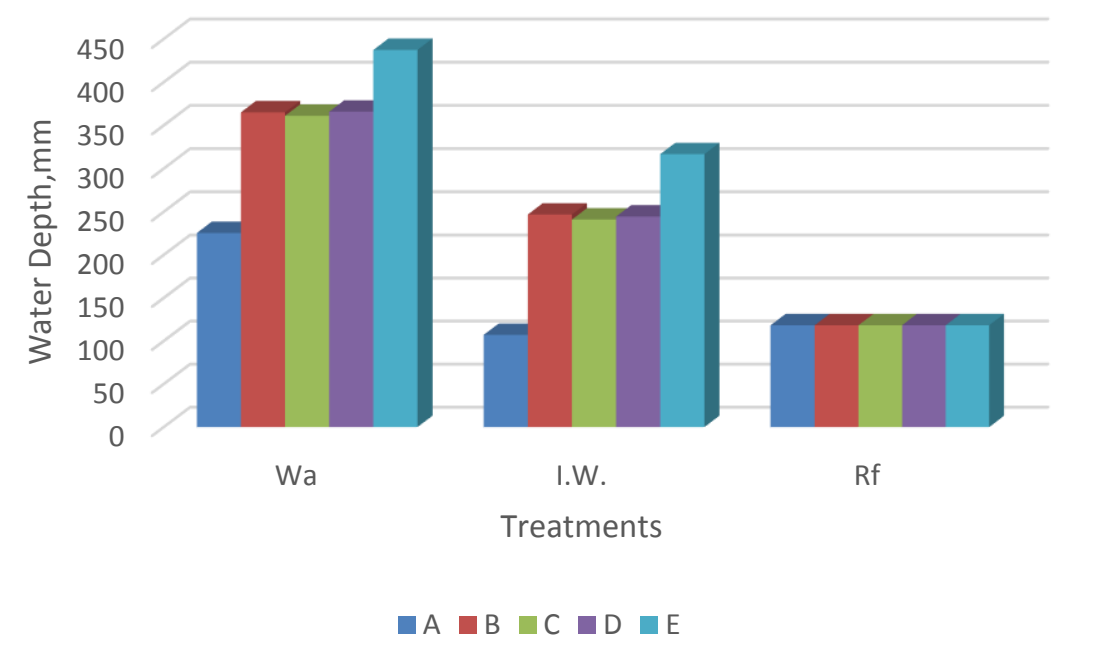

Figure 1: Mean of the two seasons for water applied $(\mathrm{mm})$; irrigation water and rainfall as obtained by irrigation treatments for wheat.

\section{Consumptive use (CU).}

From Table 5, which presented the seasonal values of $\mathrm{CU}$ and its rate for different watering treatments, it is cleared that $\mathrm{CU}$ has the same trend with that of Wa. As illustrated in Figure 2, the traditional irrigation treatment $\mathrm{E}$ without missing irrigation at any growth stage i.e. full irrigation treatment has the highest value of CU and vice versa for the rainfed treatment A. Mean seasonal CU values for the two seasons could be arranged in a descending order as 351.9> 292.6> 290.7> 287.7 and $173.9 \mathrm{~mm}$ for treatments E, B, D, C and A respectively. The corresponding $\mathrm{CU}$ rate values for the stated treatments were $1.9>1.6=1.6>1.5$ and $0.9 \mathrm{~mm}^{\text {day }}{ }^{-1}$.

Table 5. Seasonal water consumptive use (CU) for wheat as affected by irrigation treatments in the two growing

\begin{tabular}{|c|c|c|c|c|c|c|}
\hline \multirow{2}{*}{$\begin{array}{l}\text { Season } \\
\text { Treatment }\end{array}$} & \multicolumn{2}{|l|}{$1^{\text {st }}$ season } & \multicolumn{2}{|c|}{$2^{\text {nd }}$ season } & \multicolumn{2}{|l|}{ Mean } \\
\hline & $\begin{array}{l}\mathbf{C U} \\
\mathrm{mm}\end{array}$ & $\begin{array}{l}\text { Rate } \\
\mathrm{mm} \mathrm{day}^{-1}\end{array}$ & $\begin{array}{c}\mathbf{C U} \\
\mathrm{mm}\end{array}$ & $\begin{array}{l}\text { Rate } \\
\text { mm day }^{-1}\end{array}$ & $\begin{array}{c}\mathbf{C U} \\
\mathrm{mm}\end{array}$ & $\begin{array}{l}\text { Rate } \\
\text { mm day }^{-1}\end{array}$ \\
\hline A & 184.4 & 1.0 & 163.3 & 0.9 & 173.9 & 0.9 \\
\hline B & 309.9 & 1.6 & 275.3 & 1.5 & 292.6 & 1.6 \\
\hline $\mathbf{C}$ & 296.7 & 1.5 & 278.7 & 1.5 & 287.7 & 1.5 \\
\hline D & 298.7 & 1.6 & 282.7 & 1.6 & 290.7 & 1.6 \\
\hline $\mathbf{E}$ & 360.5 & 1.9 & 343.4 & 1.9 & 351.9 & 1.9 \\
\hline
\end{tabular}

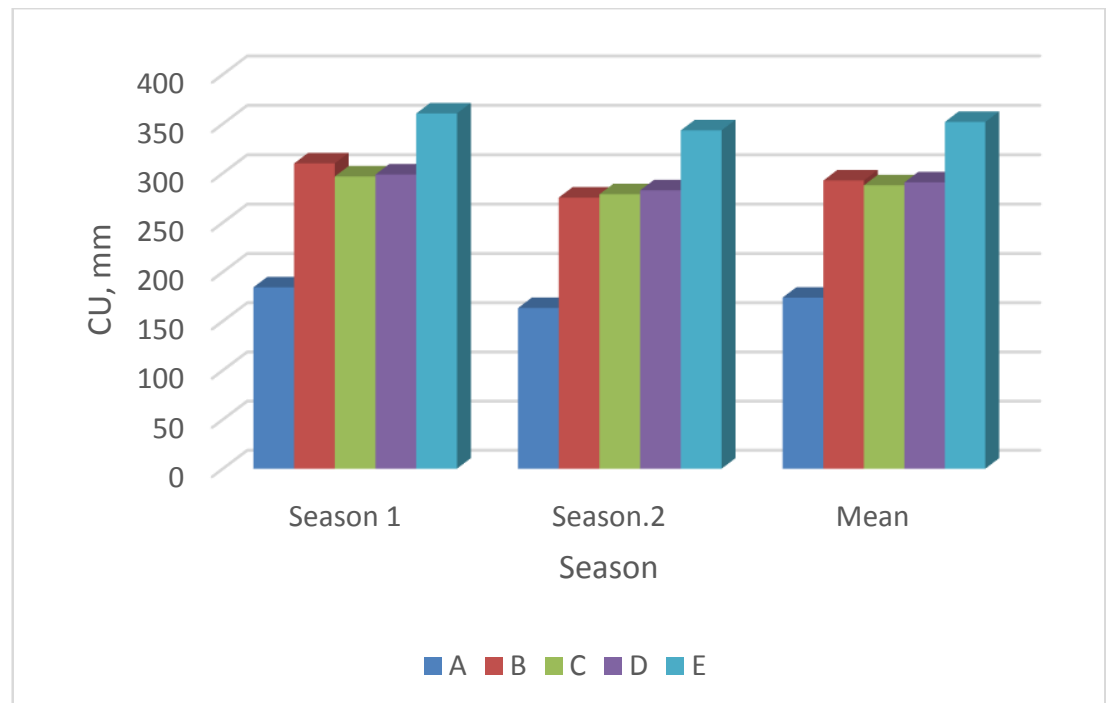

Fig. (2): Seasonal water consumptive use $(\mathrm{mm})$ for wheat as obtained by irrigation treatments in the two growing seasons. 


\section{Effect of irrigation treatments on yield and yield components for wheat crop:}

Data shown in Table 6-aand illustrated in Fig.3 show that irrigation treatments havepositive significant effect on yield in the two growing seasons. The highest mean values of grains+straw, grain and straw yield were 22,479.1, 6,270.1 and $15972.7 \mathrm{kgha}^{-1}(1 \mathrm{fed} .=0.42 \mathrm{ha})$ which were obtained forthe traditional watering without skipping irrigation at any growth stage (Treatment E). On the other hand, the corresponding lowest values were $14,822.6,3,550.0$ and $11272.4 \mathrm{kgha}^{-1}$ resulted under rainfall treatment(Treatment A).Increasing wheat yield with no skipping irrigations was due to the sufficient available soil moisture in the root zone. Compared with the highest grain yield obtained from the traditional irrigation treatment $\mathrm{E}$, the reduction percentage in grain yield was 43.4, 21.2, 11.2 and $5.9 \%$ for rainfall and supplemental irrigation treatments of A, B, C, and D, respectively.Same trend was observed regarding both grains+straw and straw yields. Application of onlythe sowing irrigation plus rainfall (Treatment.A) gave 60\% of the highest wheat grain yield.Reduction in wheat grain yield due to skipping irrigation at different growth stages could be arranged in a descending order as vegetative > flowering $>$ milking. Thus missing irrigation during milking stage resulted in a slight grain decrease and gave almost $94 \%$ of the highest yield.On the other hand, missing irrigation during vegetative stage gave $80 \%$ and skipping watering at flowering gave $90 \%$ of the highest grain yield.Itshould be noticed that there is no clear difference between grain yield of treatments B and C. This finding could be attributed to rainfall replenishing the difference in yield of treatments B and C. Almost, same trend was observed for grains+straw and straw yields. These results agree with those obtained byAlderfasi(2009)who found that low soil moisture content caused an irreversible loss in yield potential.

Regarding harvest index (HI), there was no significant difference between treatments. Mmean values of $\mathrm{HI}$ ranged between 0.24 and 0.28 .

For plant height, data in Table 6-b show that plant heightwas significantly affectedbyirrigation treatments. The traditional treatment $\mathrm{E}$ has exceeding in plant height with $8.99,7.24,3.69$ and $2.89 \%$ in comparison with treatments $\mathrm{A}, \mathrm{B}, \mathrm{C}$ and $\mathrm{D}$, respectively. These results are in a good agreement with those obtained byAlderfasi (2009).

The same Table $6 \mathrm{~b}$ shows that the 1000-grain weight of wheat was not significantly affectedby irrigation treatments. The mean values of 1000-grain weight ranged between $38.1 \mathrm{~g}$ for treatment $\mathrm{A}$ and $41.2 \mathrm{~g}$ for treatment $\mathrm{E}$ with an overall mean of $39.6 \mathrm{~g}$. On the other hand, both attributes of number of spikes $\mathrm{m}^{-2}$ and spike length were significantly affectedby irrigation treatments. In this regard, values of spikes $\mathrm{m}^{-2}$ could be arranged in descending order as 424.7> 406.0> 354.0> 313.4> 295.4, while the values of spike length were 10.9> 10.8> 10.5> $10.2>9.2 \mathrm{~cm}$ for treatments E, D, C, B and A, respectively.Same trend was observed by Panda et al (2003). 
Table 6. Effect of irrigation treatments on yield, harvest index and yield components forWheat.

a- Wheat yield and harvest index

\begin{tabular}{|c|c|c|c|c|c|c|c|c|c|c|c|c|}
\hline \multirow[t]{2}{*}{ Trt. } & \multicolumn{3}{|c|}{$\begin{array}{l}\text { Grain+straw yield, } \\
\text { Mg ha }^{-1} \text {. }\end{array}$} & \multicolumn{3}{|c|}{$\begin{array}{l}\text { Grain yield, } \\
\text { Mg ha-1 }^{-1}\end{array}$} & \multicolumn{3}{|c|}{$\begin{array}{l}\text { Straw yield, } \\
\text { Mg ha-1. }^{-1}\end{array}$} & \multicolumn{3}{|c|}{ Harvest index } \\
\hline & $1^{\text {st }}$ season & $2^{\text {nd }}$ season & Mean & $1^{\text {st }}$ season & $2^{\text {nd }}$ season & Mean & $1^{\text {st }}$ season & $2^{\text {nd }}$ season & Mean & $1^{\text {st }}$ season & $2^{\text {nd }}$ season & Mean \\
\hline $\mathbf{A}$ & $14.661 \mathrm{~b}$ & $14.970 \mathrm{~b}$ & 14.816 & $3.445 \mathrm{~d}$ & $3.633 \mathrm{c}$ & 3.550 & $11.215 \mathrm{~b}$ & $11.330 \mathrm{~b}$ & 11.272 & 0.237 & 0.244 & 0.241 \\
\hline B & $17.866 \mathrm{ab}$ & $20.392 \mathrm{a}$ & 19.129 & $4.814 \mathrm{c}$ & $5.071 \mathrm{~b}$ & 4.993 & $13.052 \mathrm{ab}$ & $15.384 \mathrm{a}$ & 14.210 & 0.271 & 0.246 & 0.259 \\
\hline $\mathbf{C}$ & $19.326 \mathrm{a}$ & $22.391 \mathrm{a}$ & 20.858 & $5.405 \mathrm{bc}$ & $5.720 \mathrm{ab}$ & 5.566 & $13.921 \mathrm{ab}$ & $16.663 \mathrm{a}$ & 15.292 & 0.280 & 0.257 & 0.269 \\
\hline D & $20.658 \mathrm{a}$ & $22.658 \mathrm{a}$ & 21.658 & $5.854 \mathrm{ab}$ & $5.949 \mathrm{a}$ & 5.901 & $14.804 \mathrm{a}$ & $17.142 \mathrm{a}$ & 15.973 & 0.284 & 0.264 & 0.274 \\
\hline $\mathbf{E}$ & $21.991 \mathrm{a}$ & $22.967 \mathrm{a}$ & 22.479 & $6.409 \mathrm{a}$ & $6.131 \mathrm{a}$ & 6.270 & $15.583 \mathrm{a}$ & $16.793 \mathrm{a}$ & 16.188 & 0.292 & 0.268 & 0.280 \\
\hline F-test & $* *$ & $* *$ & & $* * *$ & ** & & $*$ & $*$ & & Ns & Ns & \\
\hline $\begin{array}{l}\text { LSD } \\
5 \%\end{array}$ & 2.873 & 3.486 & & 0.513 & 0.512 & & 2.612 & 3.170 & & ------- & ------- & \\
\hline $\begin{array}{l}\text { LSD } \\
1 \%\end{array}$ & 4.127 & 5.009 & & 0.737 & 0.736 & & --------- & & & -------- & -------- & \\
\hline
\end{tabular}

*Mg: meggagram $=10^{6} \mathrm{~g}$

b- Yield components

\begin{tabular}{|c|c|c|c|c|c|c|c|c|c|c|c|c|}
\hline \multirow[t]{2}{*}{ Trt. } & \multicolumn{3}{|c|}{$\begin{array}{l}\text { Plant height, } \\
\text { cm. }\end{array}$} & \multicolumn{3}{|c|}{$\begin{array}{l}\text { 1000-grain weight, } \\
\text { g. }\end{array}$} & \multicolumn{3}{|c|}{ No. Spike/m² } & \multicolumn{3}{|c|}{$\begin{array}{l}\text { Spike Length, } \\
\text { cm }\end{array}$} \\
\hline & $1^{\text {st }}$ season & $2^{\text {nd }}$ season & Mean & $1^{\text {st }}$ season & $2^{\text {nd }}$ season & Mean & $1^{\text {st }}$ season & $2^{\text {nd }}$ season & Mean & $1^{\text {st }}$ season & $2^{\text {nd }}$ season & Mean \\
\hline $\mathbf{A}$ & $98.1 \mathrm{~b}$ & 97.7 & 97.9 & 38.07 & 38.12 & 38.10 & $258.7 \mathrm{c}$ & $332.0 \mathrm{c}$ & 295.4 & $9.43 \mathrm{~b}$ & $9.0 \mathrm{~b}$ & 9.22 \\
\hline B & $100.1 \mathrm{~b}$ & 98.8 & 99.5 & 38.73 & 38.47 & 38.60 & $284.0 \mathrm{bc}$ & $342.7 \mathrm{bc}$ & 313.4 & $10.43 \mathrm{a}$ & $10.0 \mathrm{ab}$ & 10.22 \\
\hline $\mathrm{C}$ & $103.4 \mathrm{ab}$ & 102.3 & 102.9 & 39.87 & 39.67 & 39.77 & $336 \mathrm{~b}$ & $372.0 \mathrm{abc}$ & 354.0 & $10.37 \mathrm{a}$ & $10.53 \mathrm{a}$ & 10.45 \\
\hline D & $104.3 \mathrm{ab}$ & 103.0 & 103.7 & 40.63 & 40.27 & 40.45 & $409.3 \mathrm{a}$ & $402.7 \mathrm{ab}$ & 406.0 & $10.70 \mathrm{a}$ & $10.90 \mathrm{a}$ & 10.8 \\
\hline $\mathbf{E}$ & $108.4 \mathrm{a}$ & 104.9 & 106.7 & 40.77 & 41.70 & 41.24 & $433.3 \mathrm{a}$ & $416.0 \mathrm{a}$ & 424.7 & $10.80 \mathrm{a}$ & $11.00 \mathrm{a}$ & 10.9 \\
\hline F-test & $*$ & Ns & & Ns & Ns & & $* *$ & $*$ & & $*$ & $*$ & \\
\hline LSD $5 \%$ & 5.811 & ------- & & -------- & ------- & & 69.634 & 64.240 & & 0.778 & 1.1503 & \\
\hline LSD 1\% & ------ & ------- & & -------- & -------- & & 100 & $\begin{array}{l}------- \\
\end{array}$ & & ------ & $\begin{array}{l}------ \\
\end{array}$ & \\
\hline
\end{tabular}




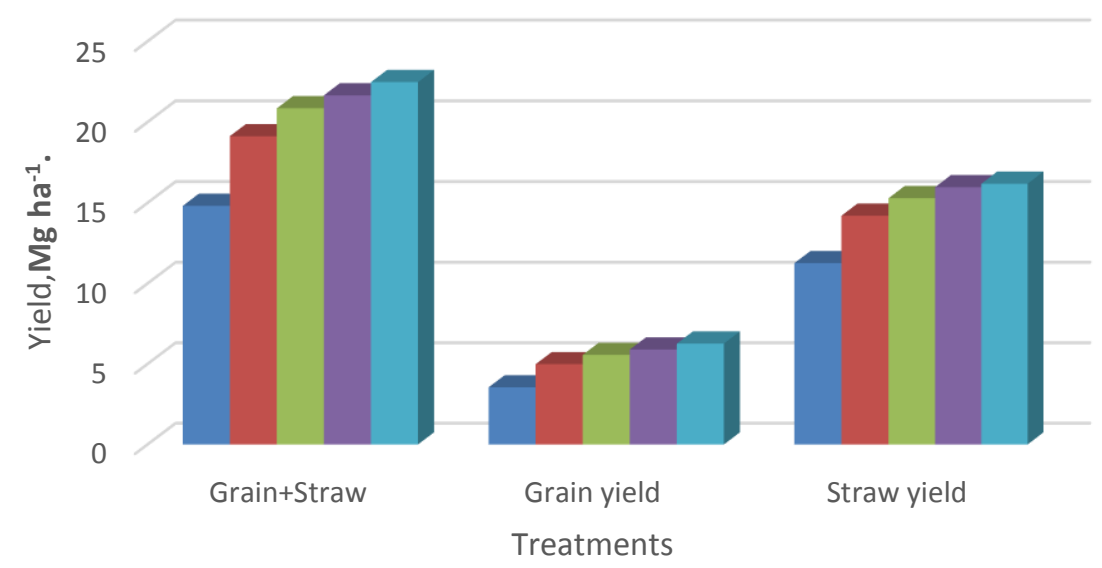

$\square \mathrm{A} \square \mathrm{B} \square \mathrm{C} \square \mathrm{D} \square \mathrm{E}$

Figure 3: Mean of wheat yield as affected by irrigation treatments.

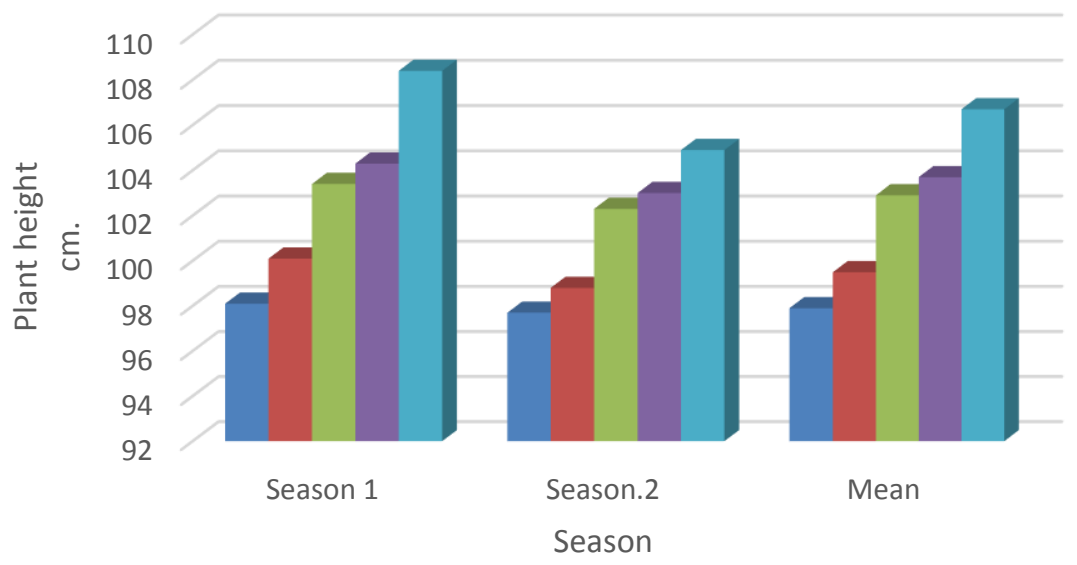

$\square \mathrm{A} \square \mathrm{B} \square \mathrm{C} \square \mathrm{D} \square \mathrm{E}$

Figure 4: Effect of irrigation treatments on plant height $(\mathrm{cm})$ for wheat.

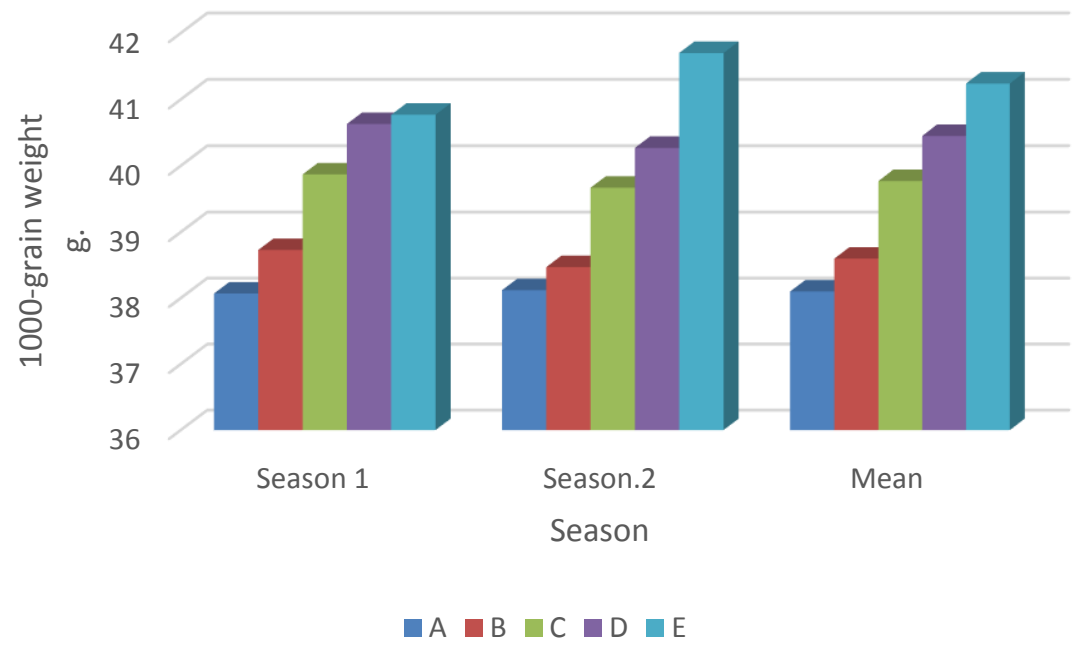

Figure 5: Effect of irrigation treatments on 1000-grain weight (gm.) for wheat. 
Water productivity (WP, $\mathrm{kgm}^{-3}$ ) and productivity of applied water (PWa, $\mathrm{kg} \mathrm{m}^{-3}$ )

Water productivity (WP) and productivity of applied water (PWa) are two parameters of crop-water functions which reflect the capability of consumed water (WP) or applied water (PWa) in producing crop yield, values of the two parameters are shown in figures 6 and 7. The mean seasonal values of WP show that the highest values 2.04 and $2.03 \mathrm{kgm}^{-3}$ consumed water were produced with rainfed and skipping irrigation at milking stage treatments $\mathrm{A}$ and $\mathrm{D}$, respectively. The lowest value $1.69 \mathrm{kgm}^{-3}$ was for skipping irrigation at vegetative growth stage treatment B. Regarding productivity of applied water (PWa), values as shown in fig 7, show rather similar trends with thoseof WP. Values of PWa could be arranged in a descending order as $1.61>1.58>1.54>$ $1.43>1.35 \mathrm{kgm}^{-3}$ applied water for treatments $\mathrm{D}, \mathrm{A}$, $\mathrm{C}, \mathrm{E}$ and $\mathrm{B}$ respectively.

These results are similar to those observedbyFarahani and Chaichi (2012)whoconcluded that deficit irrigation methods are those irrigation methods that yield increases per given water unit (water productivity).

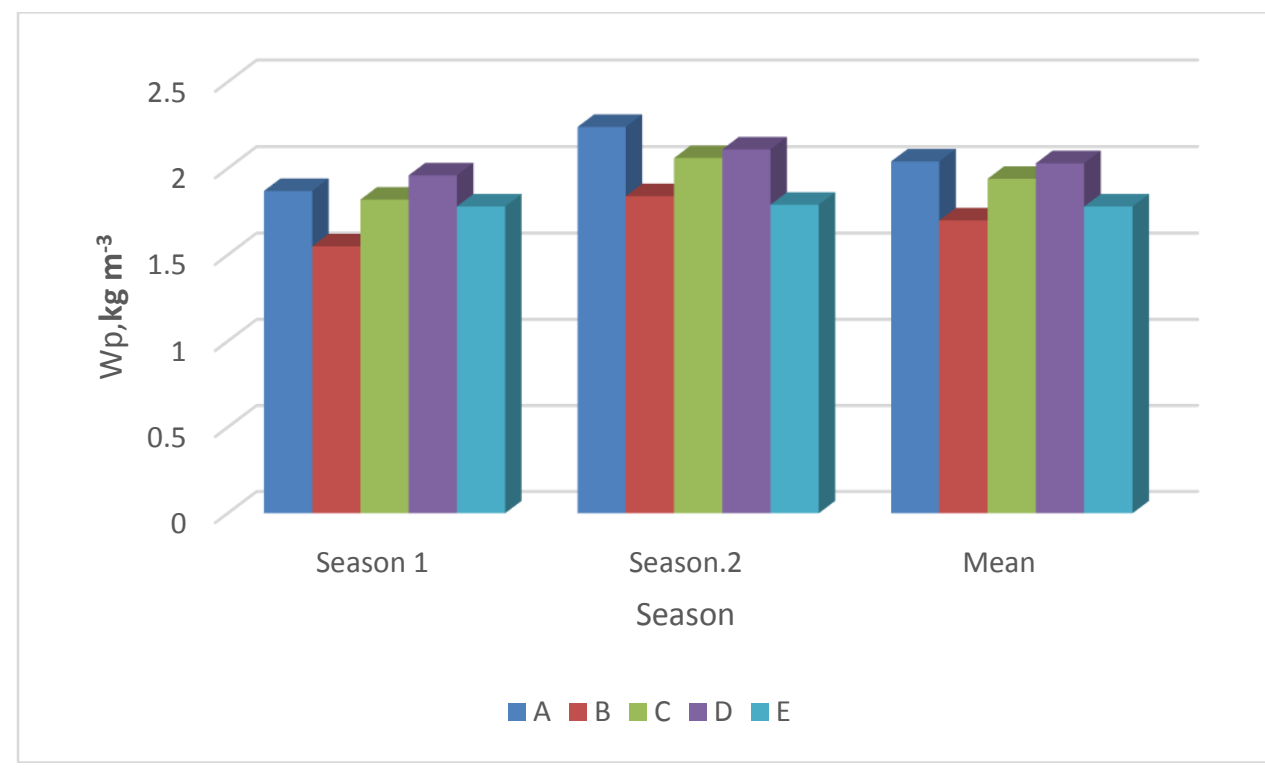

Figure 6: Effect of irrigation treatments on water productivity (WP) for wheat.

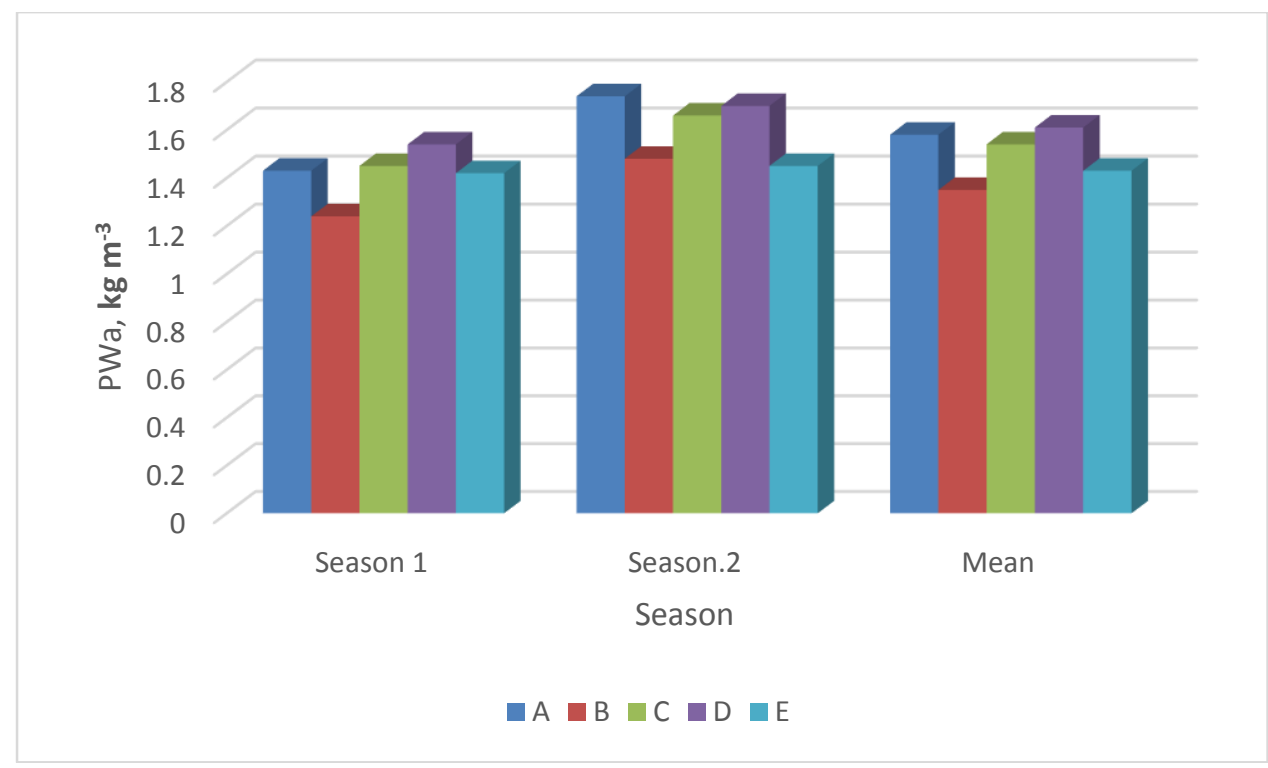

Figure 7: Effect of irrigation treatments on productivity of water applied (PWa) for wheat. 
Water saving (WS).

Regarding water saving (Ws), by comparing the seasonal $\mathrm{Wa}$ (Table 4) of rainfed as well the skipping treatments with $\mathrm{Wa}$ for the full irrigation treatment $\mathrm{E}$, mean values of Ws for the two growing seasons were $48.5,16.5,17.4$ and $16.3 \%$. for treatments A, B, C and D, respectively. Therefore, by applying only the sowing irrigation (rainfed treatment A), almost half of the full irrigation water could be saved, but the corresponding reduction in crop yield should be taken into consideration. However, the overall average Ws for skipping irrigation at different wheat growth stages treatments $\mathrm{B}, \mathrm{C}$ and $\mathrm{D}$ was $17 \%$.

Comparingrainfed and skipping irrigation treatments with full irrigation treatment $\mathrm{E}$, the decrease in grain yield (Table 6) was 43.4, 21.2, 11.2 and 5.9\% for treatments $\mathrm{A}, \mathrm{B}, \mathrm{C}$ and $\mathrm{D}$, respectively. Thus skipping irrigation at milking stage resulted in the lowest reduction in wheat grain yield and vice versa regarding the vegetative stage.

\section{Conclusion and recommendations}

North Nile Deltahas a fair amount of rainfall, therefore the impact of it on water applied and crop yield of wheat is an effective way in maximizing its water productivity (WP). Rainfall treatment A (given only sowing irrigation) has the lowest values of water applied (Wa), consumptive use (CU) and crop yield and vice versa for $\mathrm{Wp}$ and productivity of applied water (PWa). On the other hand, treatment $\mathrm{E}$ of no missing irrigation at any growth stage of growth has the adverse trend of the stated parameters. Mean average contribution of rainfall in water applied (Wa) ranged between 52.5 and $27.1 \%$ for treatments A and E, respectively. Nearly $60 \%$ of the highest wheat yield of treatment $\mathrm{E}$ was produced under rainfall treatment A. Skipping irrigation at milking stage (Trt D) resulted in water saving of about $16 \%$ which amounted to $714 \mathrm{~m}^{3} \mathrm{ha}^{-1}$, with decrease of only $6 \%$ of the highest grain yield..

Therefore, in case of enough water availability, it could irrigate wheat with three irrigations following sowing. Skipping irrigation at milking stage could save $16 \%$ ofirrigation water with a slight decrease in wheat grain yield. Rainfall treatment of sowing irrigation plus rainfall (treatment A) produced nearly $60 \%$ of the highest wheat grain yield.

More investigations should be carried outto emphasize the role of conjunctive use of rainfall with irrigation for winter crops in North Nile Delta, particularly under the water shortage status facing Egypt.

\section{References}

Alderfasi, A. A. 2009. Integrated use of Potassium fertilizer and water schedules on growth and yield of two wheat genotypes under Arid Environment Saudi Arabia. 1) Effect on yield and yield component characters. World J. Agric. Sci. 5(2):221-227.

AGRI-FACTS 2011. Irrigation Scheduling for Winter Wheat in Southern Alberta. Alberta Agriculture and Forestry, Alberta Ag-Info Centre, Canada

Allen, R. G. 1991.Irrigation Engineering principles. Utah State Univ.

Bos, M.G. 1980. Irrigation efficiencies at crop production level. ICID. Bulletin 29, 2: 189-260 New Delhi.

.Carter, K. E., and Stoker, R.1985. Effects of irrigation and sowing date on yield and quality of barley and wheat. New Zealand Journal of Experimental Agriculture, 13:1, 77-83.

Farahani, S. M., and Chaichi,M. R. 2012. Deficit (limited) irrigation- A method for higher water profitability. Irrigation Systems and Practices in Challenging Environments. Fac.ofAgric, Univ. of Tehran.

Hansen, V.; Israelsen,W., and Stringharm,Q.E.1979. Irrigation principles and practices, 4th (ed.), John Willey and Sons,.USA.

Harris, G.; Payero,J.; Jackson,R., and Peake,A.2012. Irrigated wheat-best practice guide. DAFF Queensland, Australia.

Jackson, M. 1. 1973. Soil chemical analysis. Prentice Hall of India, LTD, New Delhi,India.

James, L. G. 1988. Principles of farm irrigation system design. John Willey and Sons Inc., NY, USA.

Kharrou, M., H.; Er-Raki,S.; Chehbouni,A.; Duchemin,B.; Simonneaux,V.; LePage,M.; Quzine,L., andJarian,L. 2011. Water use efficiency and yield of winter wheat under different irrigation regimes in a semi-arid region. Agric. Sci., 2(3): 273-282.

Kirkpatrick, A.,Browning,L.;Bauder,W.; Waskom,R.;Neibauer,M.,and Cardon,G.2006. Irrigation with limited water supplies. A practical guide to choosing crops well-suited to limited irrigation. Montana State University Extension. EB169.

Klute, A.C 1986. Water retention: laboratory Methods. In: A. Koute (ed.), Methods of soil analysis, $2^{\text {nd }}$ Ed. Part 1: Physical and mineralogical methods. Agronomy Monogr.9, ASA, Madison, W1, USA, pp:. 635 - 660.

Michael, A. M. 1978. Irrigation-Theory and practices. Vikas Publishing House, New Delhi.India.

Neibling, H.; Rogers,C.W.; and Qureshi,Z. 2017. Scheduling the final irrigation for wheat and barley. University of Idaho Extension, BUL 912, USA. 
Novica, V. (1979). Irrigation of agriculture crops. Fac. Agric Press, Novi Sad, Yugoslavia.

Panda, R.K., Behera,S. K.; andKashyap,P. S. 2003. Effective management of irrigation water for wheat crop under stressed conditions using simulation modeling. $7^{\text {th }}$ Int.. Water Techn. Conf., Egypt, 1-3 April 2003.
Staricka, J. A.;Tjelde,T. J.; and Bergman,J. W. 2016. Reduced irrigation on durum wheat and barley production in Northwest North Dakota. Int. Meetings Amer. Soc. of Agron. Crop Sci. Soc. Amer. Soil Sci. Soc. of Amer, 2016.. 
ترابط مياه الري والامطار وتأثيرهما على إنتاجية محصول القمح في شمال دلتا النيل

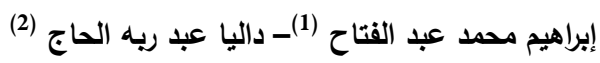

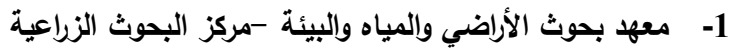

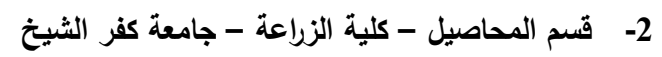

أقيمت تجربة حقلية بمحطة البحوث الزراعية بسخا بمحافظة كفر الثيخ فى شمال وسط دلنا النيل لموسمين 2016/2015 و 2017/2016 بهدف تعظيم

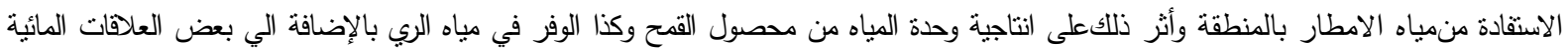

للمحصول.

وفيما يلي أهم الننائج المتحصل عليها:

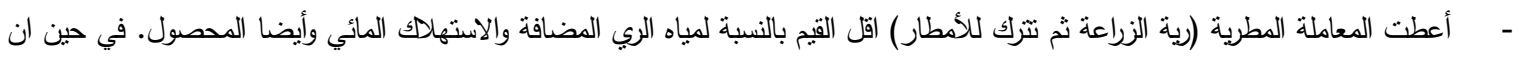

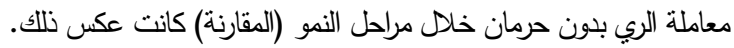

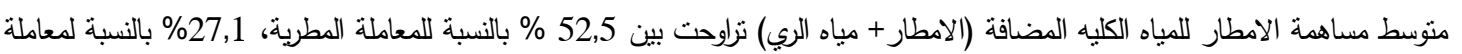

المقارنة.

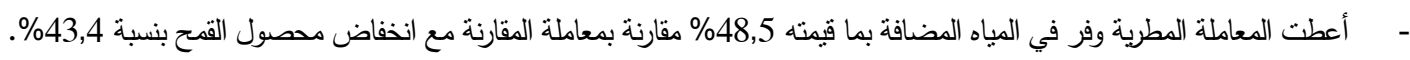

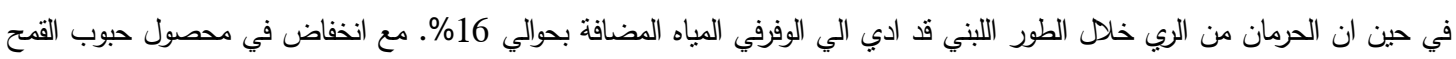
بحوالي 6\% فقط. - أي ان المعاملة المطرية قد أعطت حوالي 60\% من محصول الحبوب.

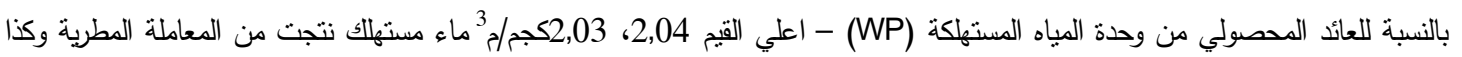
معاملة الحرمان من الري خلال الطور اللبني.

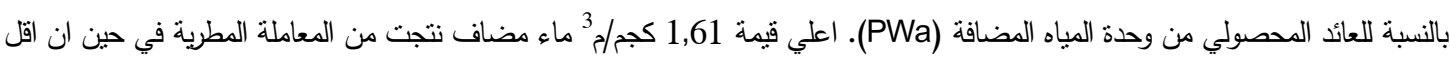
القيم 1,35 كجم/3 ماء مضاف نتجت من معاملة الحرمان خالد النمو الخضري. - وجود معنوية في معظم صفات المحصول حيث ازدادت القيم مع زيادة المياه المضافة والعكس بالعكس. وعليه توصي الاراسة: - - تحت ظروف نقص المياه فان المعاملة المطرية نعطي حوالي 60\% من اعلي محصول.

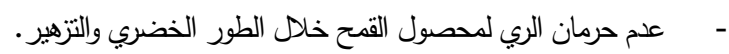

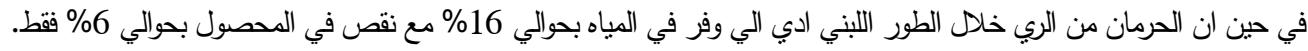

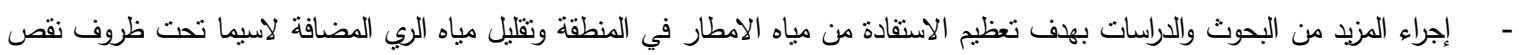

